The Editor invites authors, editors, and publishers of new bibliographic material-textbooks, reports, proceedings volumes, periodicals, papers, etc. - in engineering geology and related fields to send in announcements, copies or reprints of their material. Contributions should allow the Editor to present references in full and include the English rendering of titles and synopses originally given in other languages.

\section{NEW PUBLICATIONS RECEIVED}

Proceedings 4th international congress International. Association of Engineering Geology, India, 1982. Comptes Rendus $4^{\mathrm{e}}$ congrès international Association Internationale de Géologie de l'Ingénieur, Inde, 1982. 1982, $28 \times 21 \mathrm{~cm}$. c. 3500 pp.. 10 vols., 280 contributions Cloth, Hfl. 650/\$245/£140, 9061912660 Publication date: 31 December 1982 (Vol. 10: July 1983) Pre-publication price: Hfl.450/\$170/\$98 (Plus Hfl.25/\$10.00/£5.50 for vol.10 to be charged on publication). The official proceedings with nearly 300 papers ( 6 French, rest English) from contributors throughout the world.

Contents:

1. Engineering geological studies for environmental evaluation and development. Practical application of the clay microfabric studies (V.1. Osipov, Moscow State Univ., USSR); Monitoring of the mining complex (M.N.Buckking \& E.I.Tkachuk. Polytechn. Inst. of Novocherkassk, USSR ; Rock quality mapping of Mantolin Inland, Ontario (M.D. Johnson \& D.J. Russell, Ontario Geological Survey, Canada); The in-situ permutrity test in jointed rock Problems and investigation (H.-J. Schneider, Kavernbau \& Betriebsges., Hannover, Germany): Dimensionless logarithmic spiral tables for geotechnics (A.R. Jumikis, State Univ. of New Jersey, USA); etc.

2. Engineering geological problems of tunnelling and excavation of cavities. An assessment of theoretical models for the design of mine tunnels (R.W. Singh, B.T. Wells \& A.M.H. Zadeh, Univ. of Nottingham, (UK); Resistivity electrical prospecting and the studies of tunnels (A. Garcia Yague, Survey Geologico, Madrid, Spain): High horizontal stresses in Southern Ontario: Their origin (O.L. White \& D.J. Russell, Ontario Geological Survey, Canada): etc. 3. Soil and rock as construction material. Engineering-geological classification of rock masses (G.A. Goldovskaya \& L.V. Shanmjan, Moscow State univ., USSR); Rock index properties for prediction of rock fill behaviour (J. Delgado Rodrigues, $A$. Veiga Pinto \& $\mathrm{E}$. Maranha das Neves, Nat. Lab. Civil Engg., Lisbon, Portugal); etc. 4. Engineering geological problems of natural and man-made lakes. Evaluation of creep tests for rocks (M. Galos, Tech. Univ. Budapest. Hungary) ; etc.

5. Engineering geological problems of sea-coast and sea-bed areas. Shore management in Santa Pola Bay (Alicante, Spain) (J.J. Diez, \& M. Arenilias, Univ. Valencia); etc.

6. Seismic and seismo-tectonic investigations of engineering projects. Seismogenic phenomena in the Baikal Rift zone (Yu. B. Trzhtsinsky \& V.L. Laperdin, Inst. Earth's Crust, Irkutsk, USSR); etc.

7. History and development of engineering geology. A history of development and state-of-the art of engineering geology in USSR (Yc. M. Serge ev, USSR Acad. of Nat. Economy); History and development of engineering geology in Brazil (N.J. Chiossi, Braz. Ass. of Engg. Geology) ; etc.

MINING WITH BACKFILL. -- Proceedings of the International Symposium on "Mining with Backfill", Lulea, Sweden, 7-9 Iune 1983. Edited by S, Granholm, Lulea University of Technology, Sweden - A.A. Balkema Publishers, Rotterdam, 1983.

- Fill properties ( 7 contributions, 68 pages)

- Technology (23 contributions, 233 pages)

- Geomechanics ( 15 contributions, 151 pages)

- New development (1 contribution, 9 pages).

TROPICAL SOILS OF NIGERIA IN ENGINEERING PRACTICE. - Edited by S.A. Ola, University of Benin, Benin City.; A.A. Balkema Publishers. Rotterdam, 1983.

- Geology of Nigeria ( 3 contributions, 60 pages)

- Geotechnical properties and belaviour of soils 7 papers, 110 pages)
- Ground water and erosion ( 2 contributions 46 pages)

- Engineering and geological applications (5 contributions, 70 pages)

- Introduction to pavement design (3 contributions, 29 pages).

LIVESLEY R.K. - Finite elements, an introduction for engineers, 199 pages, Cambridge University Press. 1983.

This textbook introduces the finite-element method as an important general technique in engineering mathematics. It is written for students who have already completed a general course of vector calculus, matrix algebra and partial differential equations. The treatment introduced in this book will provide a secure foundation for more specialised work. Each chapter includes worked examples, many of which contain important applications and generalisations of the ideas in the main body of the text. The book is principally aimed at engineering students encountering the technique for the first time.

IN SITU TESTING FOR GEOTECHNICAL INVESTIGATIONS. - Proceedings of an extension course on in situ testing for geotechnical investigations /Sydney/ May-June 1983. Edited by M.C. Ervin 140 pages. A.A. Balkema, Rotterdam, April 1983

The papers in this volume formed the basis for an Extension Course on In-Situ Testing for Geotechnical Investigations held in Sydney, Australia, during eight evening sessions in May and June, 1983. The aim of the course was to provide an opportunity for geotechnical practitioners to be brought up-to-date with local methods and applications of insitu testing, and to be introduced where appropriate to developments which may not yet have had widespread local recognition.

The Organising Committee took particular care when developing the course to choose lecturers with extensive practical experience in each facet of in-situ testing covered, to ensure that those attending the course, and those using this volume of proceedings. would find the material presented to be of widespread immediate application in their day-to-day work

The course was organised by the Sydney Group of the Australian Geomechanics Society, a body jointly sponsored by The Institution of Engineers, Australia and the Australasian Institute of Mining and Metallurgy.

FEDOTOV S.A. AND MARKHININ Ye.K. - The great Tolbachik Fissure Eruption. Geological and geophysical data 1975-1976 341 pages, Cambridge University Press, 1983.

In 1975-76, a remarkable volcanic eruption took place on the Kamchatka peninsula, part of the Suviet Union's arc of active volcanoes. Dr liedotov and his colleagues studied the largest basaltic eruption in history, one of the most important volcanic events this century. During this prolonged eruption, they carried out extensive seismological, geophysical, geodetic and geochemical investigations. The results of this detailed and thorough investigation have geen collected as a series of papers under the editorship of S.A. Fedotov and collected in to this volume, the result is a classic descriptive work of a major volcanic eruption.

New Developments in Engineering geological Mapping using aerial photographs. A publication of 4 texts reprinted from the ITC Journal 1983-2, Nick Rengers being the coordinator.

1. Enginecring geological mapping from aerial photographs: the influence of photo scale on map quality and the use of stereoorthophotographs, by Varoujan Sissakian, Rob Soeters and Nick Rengers (10 pages)

2. Production of proper stereo-orthophotographs, by Kari A. Grabmaier (4 pages)

3. Computer-assisted engineering geologieal mapping, by Dirk Boonstra ( 3 pages)

4. Geo-data processing with an image processing-system, by Nanno J. Mulder (7 pages)

For IAEG members, free copies are available upon request from: D. Nick Rengers, I.T.C., P.O. Box 6, Enschede, the Netherlands. 